\title{
Archaeological Investigations at the De Zavala Point for the Proposed Penn-Texas Shoreline Improvement Project, Harris
} County, Texas

Daniel R. Potter

Center for Archaeological Research

Follow this and additional works at: https://scholarworks.sfasu.edu/ita

Part of the American Material Culture Commons, Archaeological Anthropology Commons, Environmental Studies Commons, Other American Studies Commons, Other Arts and Humanities Commons, Other History of Art, Architecture, and Archaeology Commons, and the United States History Commons

Tell us how this article helped you.

This Article is brought to you for free and open access by the Center for Regional Heritage Research at SFA ScholarWorks. It has been accepted for inclusion in Index of Texas Archaeology: Open Access Gray Literature from the Lone Star State by an authorized editor of SFA ScholarWorks. For more information, please contact cdsscholarworks@sfasu.edu. 


\section{Archaeological Investigations at the De Zavala Point for the Proposed Penn- Texas Shoreline Improvement Project, Harris County, Texas}

\section{Creative Commons License}

\section{(c) (1) (8)}

This work is licensed under a Creative Commons Attribution-NonCommercial 4.0 International License 


\section{ARCHAEOLOGICAL INVESTIGATIONS AT DE ZAVALA POINT FOR THE PROPOSED PENN-TEXAS SHORELINE IMPROVEMENT PROJECT, HARRIS COUNTY, TEXAS}

Daniel R. Potter

With an Appendix by Anne A. Fox

Center for Archaeological Research The University of Texas at San Antonio ${ }^{\circledR}$ Archaeological Survey Report, No. 203 
A list of publications offered by the Center for Archaeological Research can be obtained by sending $\$ 1.00$ to the Center for Archaeological Research, The University of Texas at San Antonio, San Antonio, Texas 78249-0658. 


\begin{abstract}
In May 1990, archaeologists for the Center of Archaeological Research, The University of Texas at San Antonio, conducted a surface survey and subsurface testing program on De Zavala Point, a small tongue of land sticking out into the Houston ship channel in Harris County. The locality has been selected for the construction of a large-vessel docking facility. Survey and testing activities were performed in order to evaluate known archaeological sites and to locate any additional archaeological remains which might be affected by dock construction and operation. In addition, the state of preservation of the important $\mathrm{De}$ Zavala historic cemetery (41 HR 487), located within the property, was evaluated. This site has been completely submerged and eroded. Extensive prehistoric archaeological remains were encountered along the shoreline of the study area. Surface and subsurface evaluation of these remains revealed that these archaeological beach deposits are not in situ, being redeposited from inundated ancient land surfaces within the modern ship channel. No significant damage to these archaeological resources is expected with the establishment of the docking facility. In fact, the proposed dock construction will likely halt further subsidence-related degradation to this important historic area. While no further archaeological research is recommended at present, careful monitoring of the initial phases of dredging and dock construction are strongly recommended to insure that any remnants of the original De Zavala home site are not destroyed. The location of this important historic building and any possible associated structures has not been established accurately.
\end{abstract}




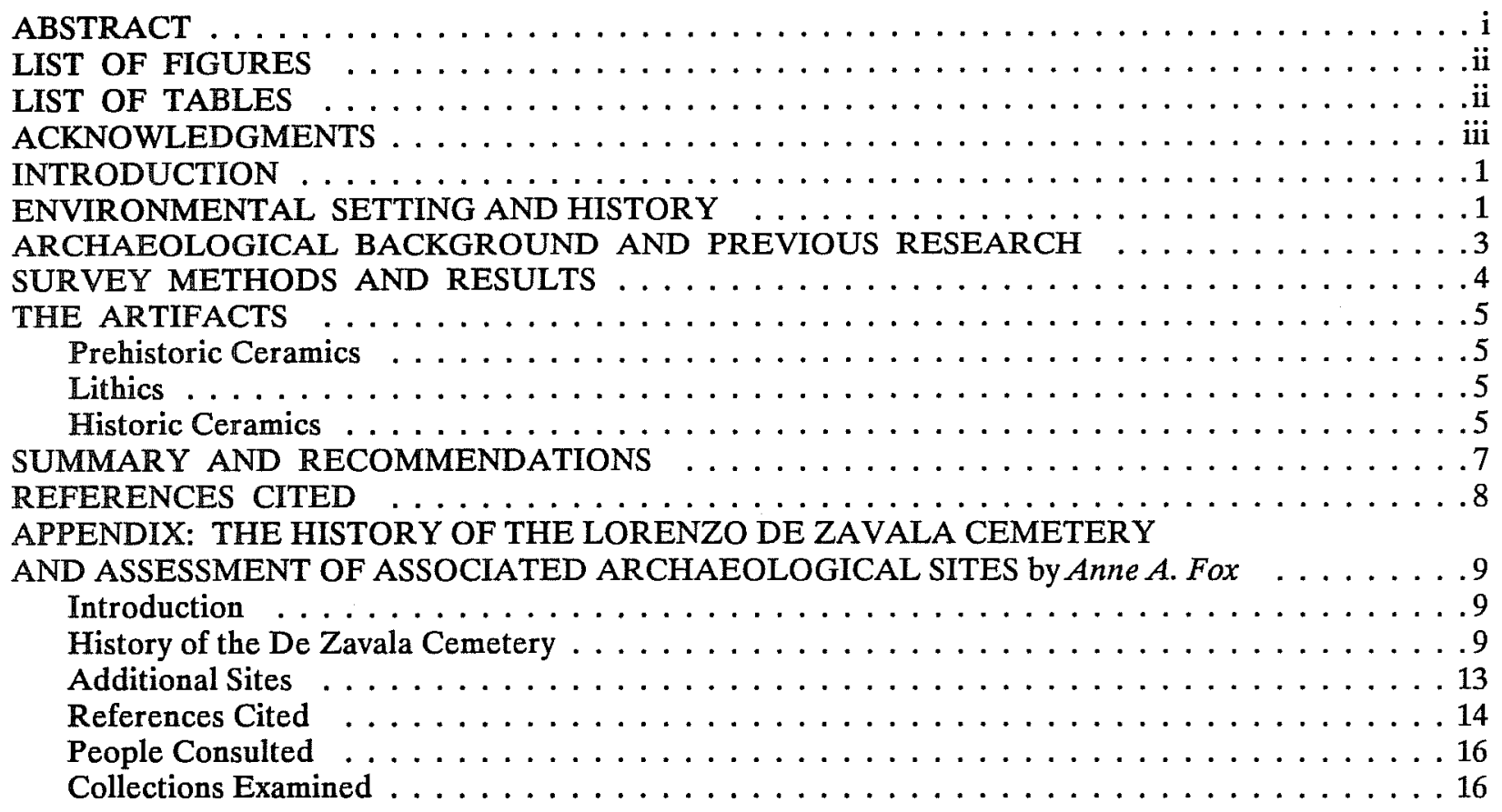

\section{LIST OF FIGURES}

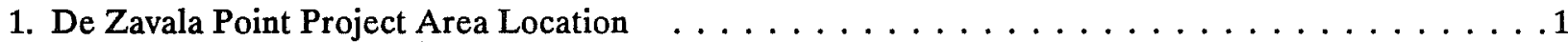

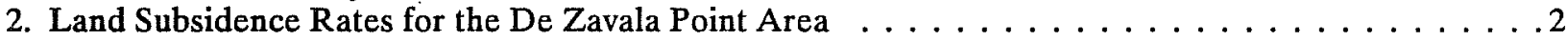

3. De Zavala Point with Archaeological Features $\ldots \ldots \ldots \ldots \ldots \ldots \ldots \ldots$

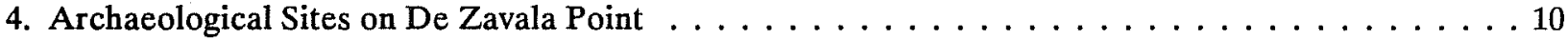

\section{LIST OF TABLES}

1. Inventory of Collected Materials from the De Zavala Point Project Site $\ldots \ldots \ldots \ldots$

2. Classification of Historic Period Ceramics from De Zavala Point . . . . . . . . . . . . . .

3. Persons Believed to Have Been Buried in De Zavala Cemetery . . . . . . . . . . . . . . . . 11

4. Markers Installed at San Jacinto Battleground . . . . . . . . . . . . . . . . 13 


\section{ACKNOWLEDGMENTS}

The author wishes to thank Mr. Bill Bayne, president, Bayne Investment Company for his assistance in completing this project. Mr. Bayne's demonstrated concern for local historical and archaeological resources is greatly appreciated. Mr. H. Raymond Smith served as field archaeologist and my wife, Maureen Brown, volunteered several days of her time in field work, laboratory, and recording activities for this project. Anne Fox, archaeologist and laboratory director of the CAR, provided a great deal of her own unpublished research and expertise concerning the historic archaeology of De Zavala Point. She has also generously included a previously unpublished paper on the De Zavala cemetery as an appendix to this report. Drafting of Figure 1 was done by Frances Meskill of the CAR staff. Jack D. Eaton, acting director of the CAR, supervised this project. The office staff at the CAR was instrumental in the preparation of this report. 



\section{INTRODUCTION}

In March 1990, Mr. William E. Bayne of Bayne Investment Company requested that archaeological investigations be carried out by the Center for Archaeological Research (CAR) at The University of Texas at San Antonio (UTSA) in order to evaluate and report on any archaeological resources which might be affected by the development of a docking facility for the Penn-Texas proposed shoreline improvement project on the Houston ship channel in Harris County, Texas. At that time several sites were recorded for the general area. Sites 41 HR 487 and 41 HR 567 were within the project area and were to be evaluated for possible inclusion on the National Register of Historic Places. Site 41 HR 39, located on adjacent property, had been previously evaluated and rejected for National Register status by CAR-UTSA personnel (Taylor 1985).

Of particular interest to the present study was the evaluation of two known sites within the project area: $41 \mathrm{HR}$ 487, the De Zavala cemetery, and $41 \mathrm{HR} 567$, an eroded prehistoric site located between the De Zavala cemetery and the current De
Zavala historical marker. The De Zavala cemetery once held the remains of Lorenzo de Zavala, signer of the Texas Declaration of Independence and first vice-president of the Republic of Texas, as well as a number of De Zavala family members.

A total of two days of field work was accomplished in May 1990. Field work included a complete surface examination of nonflooded areas, with shovel testing in areas of surficial cultural materials. Daniel Potter served as coprincipal investigator and project field director, and Jack D. Eaton, acting director of the CAR, was principal investigator. The work crew consisted of three archaeologists. All recovered materials, field notes, photographs, and other information related to this project are curated at the CAR-UTSA.

\section{ENVIRONMENTAL SETTING AND HISTORY}

The project area occupies an east-pointing projection of land on the western shore of Buffalo Bayou (Fig. 1). Immediately south of De Zavala Point is Carpenters Bayou, while the north side of the point is on the San Jacinto River, or Old River.

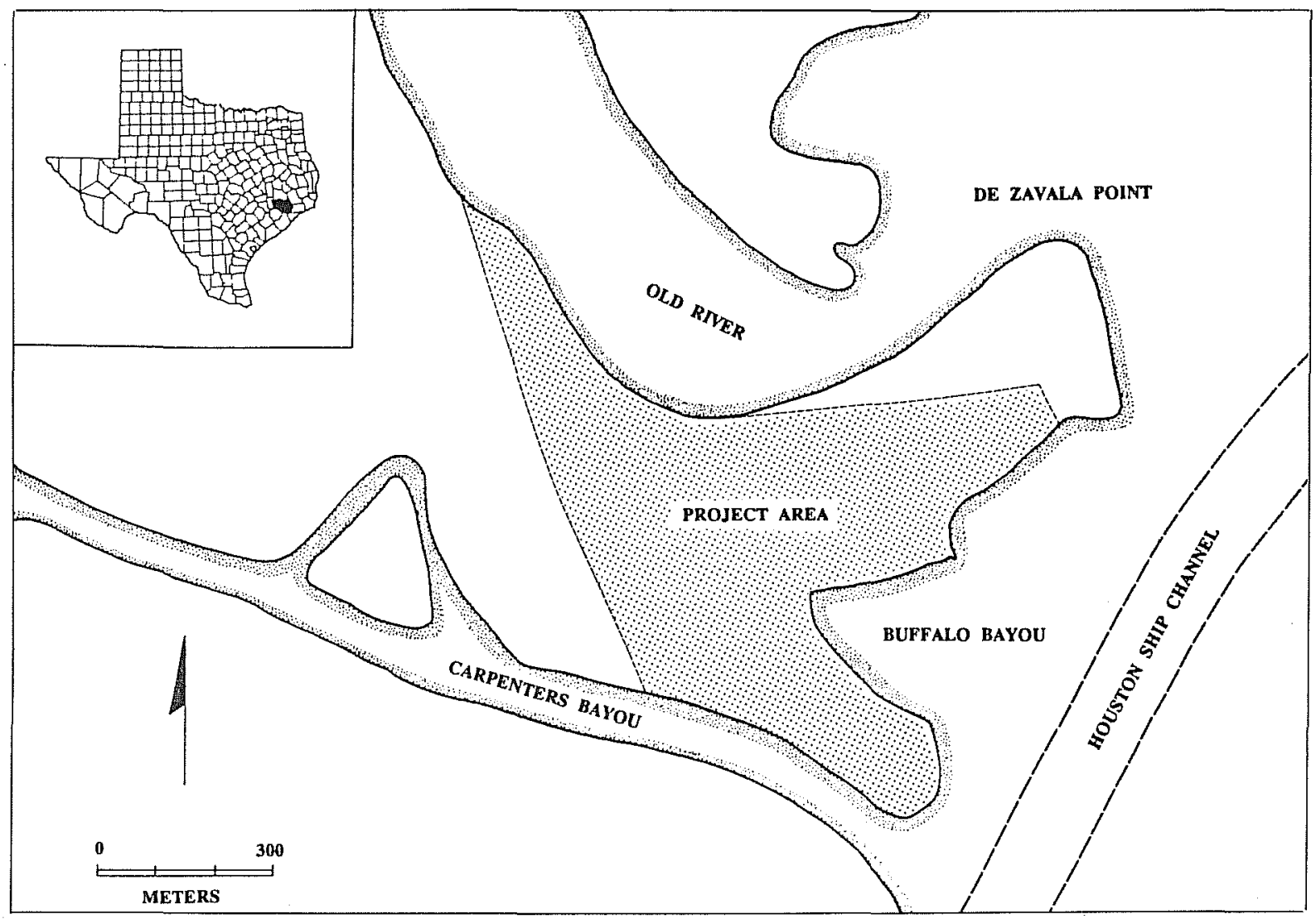

Figure 1. De Zavala Point Project Area Location. 
The point is directly across Buffalo Bayou from San Jacinto State Park.

Much of the project area is in very dense secondary vegetation, composed mainly of elm (Ulmus americana) and pine (Pinus taida) with an understory of honeysuckle (Lonicer japonica), other vines, including Parthenocissus quinquefolia, and thorn brush. During the survey, much of this area was flooded, presumably due to unusually high rainfall experienced in this region previous to the project.

Soils in the project area are of the Aldine series, with an $A$ horizon of dark, clay/sand loam overlying a B horizon of clay or sandy clay (USDA 1976). There continues to be great uncertainty concerning the degree of preservation of natural soils and general topography at De Zavala Point. The field observations suggested a greatly modified land surface due to various factors, including regional subsidence, man-induced deposition of channel-dredged deposits, tidal and wave erosion, and modern construction and development. Local inhabitants of this area had also indicated that the surface relief of De Zavala Point had changed dramatically over the past 50 years. Finally, in evaluation of excavations at $41 \mathrm{HR} 39$, Taylor (1985:67) noted that historic and prehistoric materials exhibited complete vertical mixing at that site, indicating substantial disturbance. While our own testing in the present project supports Taylor's findings, Aronow (1982) has stated that while some modification is present, the bulk of the soil profiles he observed in Day's (1982) excavations on De Zavala Point were in place and relatively undisturbed. Thus it would appear that the degree to which modern disturbance has altered the archaeological record across De Zavala Point will probably not be clarified until systematic and extensive investigations by a trained geomorphologist can be completed.

One natural factor that without doubt has affected the local archaeological record is that of regional subsidence, which has claimed a substantial portion of De Zavala Point and the surrounding Houston-Galveston region in the recent past. Between 1906 and 1973, subsidence was responsible for an estimated 6.6-foot-drop in land-surface elevation at De Zavala Point (Gabrysch and Bonnet 1974; USDI n.d.). In addition, USGS figures indicate the rate of subsidence was rapidly increasing during that time, with De Zavala Point sinking at a rate of about one-third of a foot per year from 1964 to 1973 (Fig. 2).

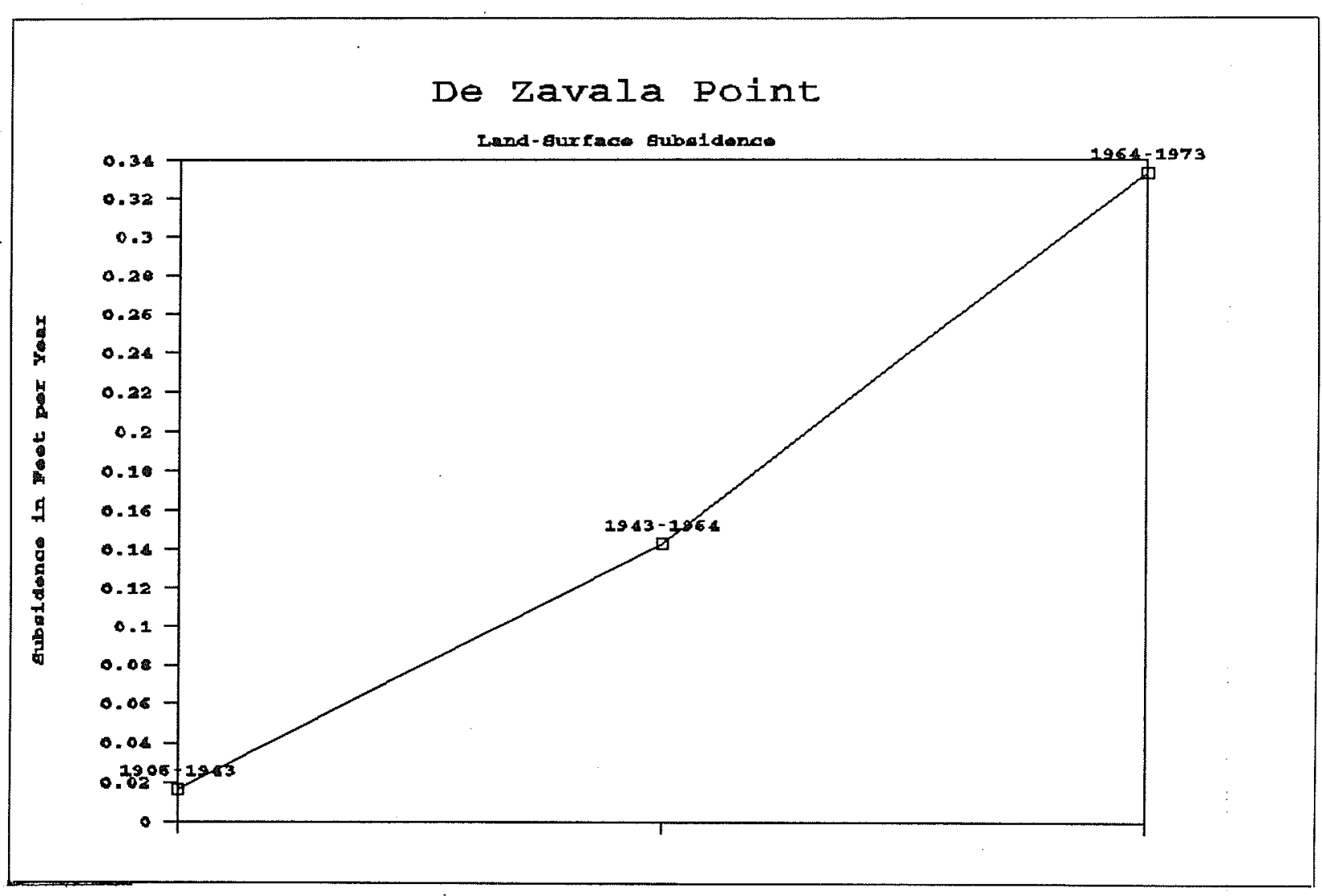

Figure 2. Land Subsidence Rates for the De Zavala Point Area. 
The rate of subsidence can also be measured through oral and written accounts of people who have witnessed the changes taking place in the area. Ms. Ella Williams, who lived as a girl on De Zavala Point sometime after 1915, remembers Buffalo Bayou as a "narrow stream" which she rowed across every day to go to school at San Jacinto (Williams 1982, cited in Vollinger 1982; during this time, subsidence was substantially less than one inch per year). By the 1970s, this picture had changed drastically, due not only to the dredging of the Buffalo Bayou/Houston ship channel, but also to the accelerating rate of subsidence, with its associated water encroachment and wave erosion. Although I have no published data past 1973, Day (1982) reports that local residents have estimated subsidence of 2.7 to $3 \mathrm{~m}$ during the last 20 years. This equals a subsidence rate of 3.5 to 5 inches per year. This data, if correct, suggests that eastern De Zavala Point has lost at least 300 to 600 linear feet (110 to $220 \mathrm{~m}$ ) of land to Buffalo Bayou since 1906, and that the rate of loss is accelerating with time (cf. Day 1982 for additional information). A final illustration of the subsidence rate in more recent times can be seen in Vollinger's (1982:14) recent account of an early 1970s newspaper article (Houston Post n.d.) which documents the De Zavala home site historical marker having been twice rescued from the Houston ship channel during a three-year period. Needless to say, if this marker did in fact accurately reflect the location of the De Zavala house (a matter of considerable uncertainty), presumably much or all of that important site has been, or is being, destroyed. We would expect that prehistoric sites, many of which would have been in close proximity to prehistoric shorelines, would be in similar, or worse straits. Thus, it seems inescapable that many of the early historic and prehistoric landscape features of De Zavala Point and the surrounding area are now most certainly submerged and lost.

\section{ARCHAEOLOGICAL BACKGROUND AND PREVIOUS RESEARCH}

Several research projects have focused on the history and prehistory of De Zavala Point and its environs, and a number of archaeological sites have been recorded in or near the project area. Many of the sites in this area were first recorded in 1956-1957 by local archaeologists W. B. Neyland and $\mathrm{R}$. B. Worthington (41 HR 37, $41 \mathrm{HR} 38$, $41 \mathrm{HR} 39,41 \mathrm{HR} 40,41 \mathrm{HR} 41,41 \mathrm{HR} 42$, $41 \mathrm{HR} 43$, and $41 \mathrm{HR} 44$ ). Since that time, a few additional sites have been recorded, including
$41 \mathrm{HR} 424$, a 20th-century navy ordnance depot; 41 HR 487, the De Zavala cemetery; and $41 \mathrm{HR}$ 567, a prehistoric shell midden. Some of these sites have been the subject of further research due to recent development of De Zavala Point. In 1973, McGuff and Ford (1974) reviewed some of the sites on De Zavala Point, and noted that while some had apparently maintained a good state of preservation, such as $41 \mathrm{HR} 39$ (this later turned out not to be the case; the site is in fact badly disturbed), others had been completely lost, sinking beneath the waters of the Houston ship channel (included here would be sites 41 HR 40 and 41 HR 41).

In 1982, several workers completed research on the history and prehistory of the project area. Espey, Huston \& Associates conducted archaeological and archival research in connection with the construction of the Falcon Cement Company terminal, north of and adjacent to the present project area (Vollinger 1982). Their research focused on $41 \mathrm{HR} 39$, a shell midden, and historic sites $41 \mathrm{HR} 424$ and $41 \mathrm{HR} 32$, the former being the naval depot mentioned previously, and the latter the supposed, but not demonstrated, location of the Lorenzo de Zavala home. Site 41 HR 32 possessed a prehistoric shell midden component in addition to its historic component. The Espey, Huston \& Associates study revealed that while cultural materials were plentiful on De Zavala Point, they occurred in somewhat ambiguous contexts.

In the same year Anne Fox of the CAR-UTSA prepared a study for the TERA Corporation, Dallas, in which she reviewed the history of the De Zavala cemetery and other sites in the area (her findings are included as an appendix to this report). Fox's report is primarily concerned with the eventful history of the De Zavala cemetery itself, but also discusses various possible locations of the first De Zavala home site as well. As with an earlier study by Brandimarte (1982), Fox could not fix the location of the house with any certainty. This lack of a precise locus for such an important historical site remains an important factor in any consideration for development of De Zavala Point. Those interested in a detailed account of the history of De Zavala Point and specifically the possible location of the De Zavala home are referred to Vollinger (1982) and Fox (see the appendix to this report).

In 1984, A. J. Taylor of the CAR-UTSA directed investigations at 41 HR 39 located near the current project area. The site was characterized as multicomponent, with prehistoric ceramic material, lithics, shell, and bone, as well as historic ceramics, 
This page has been

redacted because it

contains restricted

information. 
first recorded as a shell midden, located between the De Zavala cemetery and the grounds of the Falcon Cement Company. Two additional scatters (labeled Scatter 1 and Scatter 2 on Fig. 3) are located southwest and west of the De Zavala cemetery, respectively. All three of these scatters are identical in context and internal structure. They consist of cultural materials in a loose, soft beach-sand matrix. In all three contexts, prehistoric materials (primarily shell fragments and ceramics) are completely intermixed with modern flotsam and jetsam from the ship channel (including glass, metal, wood, and plastic items). Also present is a small quantity of 19th- and early 20th-centuries ceramic material. It is clear from our investigations that all three localities are secondary deposits, and are not of great historic or archaeological value in and of themselves. It is not as clear where the archaeological material noted in these scatters is being transported from. It is my opinion that the most likely origin for the beach material is within the ship channel itself. Due largely to the subsidence described earlier in this report, it can be expected that many sites on De Zavala Point which were once located on or near old (lower) shorelines have sunk underwater. Due to existing currents, tides, and ship channel traffic, materials from these sites are washing up on shore in specific places, creating secondary beach deposits. This would explain the total intermixture of prehistoric, historic, and modern material we observed within these deposits. Table 1 summarizes all materials recovered from surface collection and shovel testing within $41 \mathrm{HR} 567$ and Scatters 1 and 2. Because the concentrations we observed are not in fact sites but secondary deposits, there is little utility in describing them as undisturbed individual sites. Instead, all recovered materials from the project area will be described as material class.

\section{THE ARTIFACTS}

\section{PREHISTORIC CERAMICS}

Of the 53 prehistoric ceramic sherds from the project area (Table 1), all are of the type Goose Creek Plain, associated with the "Galveston Bay Focus" of Suhm, Krieger, and Jelks (1954:128-130) and conforming to ceramics described by Taylor (1985) for site 41 HR 39, just north of the present project area. Sandy paste ceramics are most common in the small sample, followed by grog and shell-tempered paste sherds. The single rim sherd within the assemblage is weathered, but possesses a straight vessel wall and direct, thin, rounded rim. Incision was not noted within the assemblage, with all sherds apparently being completely smooth, or more likely, so eroded that such decoration is no longer visible. However, asphaltum streaks or a thin, eroded red film were seen on several sherds, as was noted by Taylor (1985:32-37) at 41 HR 39.

\section{LITHICS}

Of the 21 chert objects recovered from the project area (Table 1), three projectile point fragments and five possible cores are most significant. The cores are all somewhat problematical in terms of identification. All are small pebbles (the largest measures $4.5 \times 4 \times 1.5 \mathrm{~cm}$ ), each with several small multidirectional flake removals. It may be that these are informal flake cores, although the possibility exists that natural fracturing or recent development activities have been a factor here as well.

Of the three projectile points, all are possibly very small dart points, but only one is complete enough to allow identification, and it does not readily fit into any recognized point style. Collected from the surface of Scatter 2, it is a small point, with its base broken off. The length is $4.5 \mathrm{~cm}$; width is 1.7 , and thickness is $0.78 \mathrm{~cm}$. The point possesses a thick, narrow blade with slightly pronounced shoulders, narrowing to a straight stem. Basal morphology is unknown. The two unclassified fragments originated from Scatter 1 and 41 HR 567, respectively. The presence of dart points in these deposits may indicate a nearby Archaic period site, but it is important to note that small dart points were also used into the Late Prehistoric period in the Galveston Bay region and thus these may be contemporaneous with the Goose Creek ceramics also found here (Suhm, Krieger, and Jelks 1954).

\section{HISTORIC CERAMICS}

Maureen Brown (CAR-UTSA) has examined all historic materials recovered during the project, with particular attention to ceramics, as these are often the best indicators of the age of a site. Numerically dominant within the historic artifact assemblage is glass, predominantly modern window glass. Also present is modern metal scrap, plastic, and a small amount of water-rolled bone (Table 1).

The historic ceramic assemblage (41 sherds) includes whitewares, porcelain, and stoneware (see Table 2). With the exception of five sherds, all Historic period ceramics were recovered from 


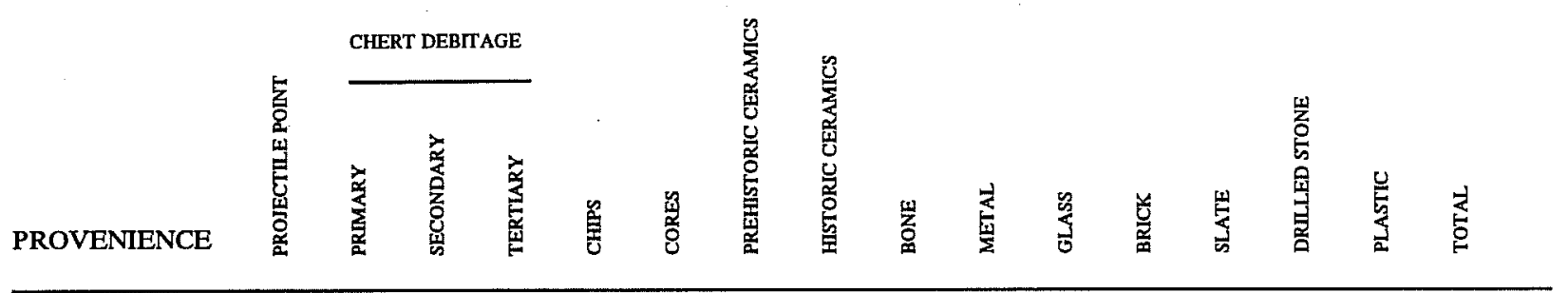

$\underline{41 \text { HR } 567}$

ST-1-1

ST-1-2

ST-2-1

ST-2-2

ST-3-1

ST-3-2

ST-3-3

ST-4-SURF.

ST-4-1

ST-4-2

ST-4-3

ST-4-4

ST-4-5

SCATTER 1

ST-5-1

ST-5-2

ST-5-3
1

$\begin{array}{lllll}3 & 6 & 1 & 10\end{array}$

16

$\begin{array}{llll}2 & 5 & 1 & 12\end{array}$

$\begin{array}{rrrrrrr} & & 1 & & & & 2 \\ & 1 & 2 & 2 & 4 & 14 & 31\end{array}$

$\begin{array}{rrrrrr}1 & 2 & 2 & 4 & 14 & 31 \\ & 1 & & & & 4\end{array}$

1

1

1

1

46

1

$\begin{array}{llll}2 & & 28 & 1 \\ 4 & 1 & 30 & \end{array}$

$\begin{array}{rrr}4 & 1 & 30 \\ 1 & & 4\end{array}$

1

10
16
12
2
31
4
6
28
30
4
4
1

1
21

16

121

16

14

3

$2 \quad 38$

5

$\begin{array}{ll}1 & 6 \\ & 2\end{array}$

SURFACE COLLECTION

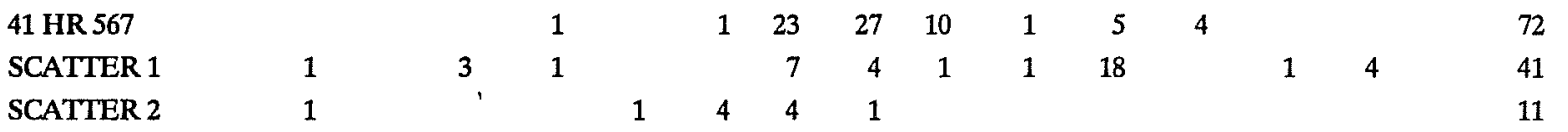

TOTAL

3

1

3

2

17
1

124

1

1

35

655

$\begin{array}{llll}41 & 40 \quad 19 & 189\end{array}$

$\begin{array}{lllll}5 & 1 & 4 & 6 & 380\end{array}$


$41 \mathrm{HR}$ 567. The earliest sherds in the assemblage consist of decorated whiteware, including transfer printed, hand decorated, and flown blue, all popular during the early to mid-19th century. Within this earliest group of ceramics are several sherds of blue transfer-printed ware with an identical design pattern. Two vessel forms are represented, probably indicating the existence of a matched set.

Undecorated whiteware, ironstone, and stoneware make up a second class of ceramics, dating from the mid to late 19 th century. Also present are ceramics which were typical of the late 19 th and early 20 th centuries.

Considered in general, the ceramic assemblage includes a range of domestic forms, such as dinnerware, storage vessels, as well as one fragment each of a washing basin and pitcher.

The earliest historic ceramics collected within the project area may be associated with the original De Zavala home site, first occupied by the family in 1835 (see appendix). The ceramics of more recent date may be associated either with the De Zavala family, or other occupants of De Zavala Point.

\section{SUMMARY AND RECOMMENDATIONS}

The research and investigations have failed to reveal any significant intact historical and/or archaeological resources within the project area. As was the case in Taylor's (1985) study of nearby site 41 HR 39, cultural materials within the project area at De Zavala Point are plentiful, but occur in disturbed contexts which nullify what would otherwise have been a very valuable archaeological zone. Of the four loci described in this report, Scatters 1 and 2 and sites $41 \mathrm{HR} 567$ and $41 \mathrm{HR} 487$, none would be adversely affected by the proposed construction within the project area. Indeed, the proposed elevation of De Zavala Point by dredging, filling, and construction would actually help matters somewhat by reducing subsidence-related erosional damage to the present land surface.

However, it must be kept in mind that there is still no precise fix on the location of the Lorenzo de Zavala house. Although our research, and that of previous projects, suggests that the house may well have been located somewhere in the $41 \mathrm{HR} 32$ and 41 HR 567 area, these are little more than educated guesses. Until such historic structures can be located precisely, all of De Zavala Point should be viewed as a very sensitive archaeological area.

TABLE 2. CLASSIFICATION OF HISTORIC PERIOD CERAMICS FROM DE ZAVALA POINT

\begin{tabular}{|c|c|c|c|c|}
\hline & 41 HR 567 & Scatter 1 & Scatter 2 & Total \\
\hline Undecorated Whiteware & 5 & 1 & & 6 \\
\hline Ironstone & 6 & & & 6 \\
\hline Transfer & 12 & & & 12 \\
\hline Hand-Painted & 2 & & & 2 \\
\hline Flown Blue & 3 & & & 3 \\
\hline Porcelain & 3 & & & 3 \\
\hline Stoneware & 5 & 3 & 1 & 9 \\
\hline TOTAL & 36 & 4 & 1 & 41 \\
\hline
\end{tabular}


It is therefore strongly recommended that archaeological monitoring be required during the initial stages of development of the entire project area. This recommendation is advanced for two reasons. First, land clearing and other preparations for construction within the project area may reveal historic remains which can finally establish without question the exact site of the De Zavala house and add to our knowledge of that important structure and the family that lived in it. Second, during CAR-UTSA investigations within the project area, poor surface conditions and limited visibility prevented full coverage of certain parts of De Zavala Point. With the clearing of these areas in preparation for construction and dredging, these portions of the project area can be thoroughly examined and recorded.

\section{REFERENCES CITED}

Aronow, S.

1982 Letter to William Day, project archaeologist for Espey, Huston \& Associates, on the geomorphology of $\mathrm{De}$ Zavala Point. October 20. Lamar University, Beaumont, Texas.

Brandimarte, $\mathrm{C}$.

1982 Archival Research for the Lorenzo De Zavala Homesite. Espey, Huston \& Associates, Job 1584. Austin, Texas.

Day, D. W.

1982 Cultural resources letter report on site testing at De Zavala Point. November 5. Espey, Huston \& Associates, Job 1584. Austin, Texas.

Gabrysch, R. K. and C. W. Bonnet

1974 Land-Surface Subsidence in the Area of Burnett, Scott and Crystal Bays Near Baytown, Texas. U. S. Geological Survey Water-Resources Investigations 21-74. September 1974.

McGuff, P. R. and M. M. Ford

1974 Galveston Bay Area, Texas: A Study in Archeological and Historical Resources in Areas Under Investigation for Navigational Improvement. Texas Archeological Survey, The University of Texas at Austin, Research Report 36.
Suhm, D. A., A. D. Krieger, and E. B. Jelks

1954 An Introductory Handbook of Texas Archeology. Bulletin of the Texas Archeological Society 25.

Taylor, A. J.

1985 Archaeological Investigations of a Shell Midden (41 HR 39) at De Zavala Point, Harris County, Texas. Center for Archaeological Research, The University of Texas at San Antonio, Archaeological Survey Report 150.

U. S. Department of the Interior (USDA)

n.d. Land-Surface Subsidence in the Houston-Galveston Region, Texas. Prepared by the U.S. Geological Survey in cooperation with the Texas Water Development Board and the cities of Houston and Galveston. Open File Report.

Vollinger, L.

1982 A Search for the De Zavala Home Site and Other Cultural Resources, Harris County, Texas. Submitted to Redec International, Paris, France. Espey, Huston \& Associates, Document No. 82180. 


\title{
APPENDIX
}

\section{THE HISTORY OF THE LORENZO DE ZAVALA CEMETERY AND ASSESSMENT OF ASSOCIATED ARCHAEOLOGICAL SITES}

\author{
Anne A. Fox
}

NOTE: This research paper was written in January 1982 for the TERA Corporation of Dallas.

\section{INTRODUCTION}

The property under discussion encompasses most of the original labor (177 acres) acquired by Lorenzo de Zavala in 1835 (Kemp 1944:374). It includes a point of land on which the original home and subsequent structures were located, and a one-acre cemetery which has belonged to the State of Texas since 1934 (Fig. 4). Severe subsidence and channel dredging in the area have caused a large percentage of the cemetery to be permanently inundated by the waters of the Houston ship channel. A small portion remains above water, and a section of a chainlink fence installed by the U.S. Government ca. 1940 currently delineates the northern boundary of the plot.

\section{HISTORY OF THE DE ZAVALA CEMETERY}

Manuel Lorenzo Justiniano de Zavala was born October 3, 1789, near Merida in Yucatan. After an active political career as a Mexican liberal, he became disillusioned with the government of Santa Anna in 1835. He moved to Texas, bought a home on Buffalo Bayou, and brought his wife and children to live there. He became a delegate from Harrisburg to the Consultation at Washington on the Brazos in 1835, and to the Convention of 1836 , where he signed the Texas Declaration of Independence. Zavala was elected ad interim vice president of the Republic of Texas on March 17 of the same year.

The Zavala home was used as a hospital for the wounded after the battle of San Jacinto, which took place across the bayou. Zavala resigned as vice president in October 1836, and died the following month. He was buried on his property, a short distance from his home.

The earliest burial believed to have been made in the cemetery, was that of General Manuel Fernandez Castrillon, who was killed during the battle of San Jacinto. According to family tradition, Lorenzo de Zavala went to the battlefield and found the body of General Castrillon, an old friend from his days in Mexico. He arranged to have the general buried near his homestead. In October of the same year, Zavala died and was buried near Castrillon (Webb Vol. I 1952:498).

From this time, the cemetery was used as a burial place for numerous members of the Zavala family. There were a number of other people buried there as well (Table 3). A marker erected by the State of Texas in 1932 stated that David Thomas, ad interim attorney general and acting secretary of war of the Republic, died in the Zavala house and was buried there in 1836.

The location of Thomas' grave is based on family tradition. There are several different theories as to where he actually died (Webb Vol. II 1952:771). There was also a marker bearing four names of men supposedly lost at sea (Baytown Sun 1969). A stone erected in 1936 by the State of Texas marked the grave of Peter Jefferson Duncan, who fought in the Texas Revolution. Duncan apparently lived in Harris County until his death in 1870 . He was a neighbor of the Zavala family (Zavala 1838).

In addition to those mentioned previously, the people of the local community were accustomed to burying in the Zavala cemetery. According to Mrs. Eppie Gertrude Higginbotham, granddaughter of Lorenzo de Zavala, the local sawmill shut down when there was a death in the community. They made a casket and held- a funeral (Baytown Sun 1968). Her son, Floyd, stated in 1969 that the cemetery had been virtually a community one for over a hundred years, that no records were kept, and that the most recent burial was in 1955 (Quick 1968).

In 1900 the idea of properly identifying Lorenzo de Zavala's grave and moving it across the bayou to the battlefield was proposed to the Daughters of the Republic of Texas Convention, and a committee was appointed to look into it (Houston Post 1900). Inspired, perhaps, by the resulting publicity, a feature article about the Zavala home and cemetery appeared in the Houston Chronicle (1921) the following January. The planned removal of Zavala 
This page has been

redacted because it

contains restricted

information. 


\section{$\underline{\text { FAMILY }}$}

Lorenzo de Zavala

Emily West de Zavala

Richardo de Zavala

Minna Wadzick de Zavala

Darwin de Zavala

Edward Theodore de Zavala

Emma Singleton de Zavala

Katherine E. de Zavala

Leroy de Zavala

Lorenzo de Zavala III

Sidney de Zavala

Henry de Zavala

Willa Folk

Amy Inez Higginbotham

Jess Higginbotham

Lillian Marie Higginbotham

Emily de Zavala Jenkins

Thomas Jenkins

Ethel K. Joyner

Katherine S. Joyner

James Singleton

Emily C. de Zavala Weaver

Ethel Gertrude Weaver Martin
1789-1836

1811-1883

1835-1906

1872-1881

1863-1882

1870-1938

1911-1914

1905-1954

1870-1906

1877-1942

1850-1871

1904-1907

1878-1915

1901-1903

1909-1912

1887-1911

1881-1912

1861-1892

$-1955$

\section{OTHERS}

Gen. Manuel Fernandez Castrillon

Died 1836

Frederick Dulitz

1873-1876

Peter Jefferson Duncan

1799-1870

Doctor Dunlap

Frederick Nitsche

1794-1863

William Nitsche

David Thomas

1809-1836

Charles E. Wilcox

1873-1909

Numerous unknown local individuals whose burials are unrecorded. 
to the San Jacinto Battlefield was mentioned briefly in this article.

The next indication that things were under way, was a flurry of letters exchanged between Miss Adina de Zavala, granddaughter of Lorenzo, and historian Charles H. Wharton and others discussing the proper time and setting for the ceremony of reburial (Wharton 1925a, 1925b, 1925c; Atkinson 1925). The result was the appointment of Adina de Zavala and her sister, Mary, to represent the Texas Historical and Landmarks Association on the occasion of the reburial to take place April 21, 1925 (Texas Historical and Landmarks Association 1925). By this time, the plans included the moving not only of Lorenzo de Zavala but his wife and General Castrillon as well.

The Houston newspaper of April 19, 1925, carried articles about the coming event (Houston Post-Dispatch 1925a; Houston Chronicle 1925). The Houston Chronicle article, replete with photographs of participating dignitaries, included biographies of Zavala and Castrillon. The list of those due to participate in the "quiet, unofficial burial ceremony" to take place at sunrise was an impressive one. The ceremony was to be under the direction of Clarence $R$. Wharton, prominent Houston attorney and Texas historian, and with Monsignor J. M. Kirwin of Galveston officiating. Other participants were to include C. H. Milby of the San Jacinto Park Board; Miss Adina de Zavala; Mrs. Concepcion R. Castrillon Gibler, relation of General Castrillon; J. B. Fernandez, Mexican counsul; Major Calvin Garwood and Colonel J. S. Hoover, unofficial military representatives. The Sons and Daughters of the Republic of Texas, it was announced, would place suitable monuments of the Zavalas' graves.

From this time onward, there was nothing further about the reburial ceremony in the press. Detailed articles about the San Jacinto Day celebrations in the Houston and Galveston papers on April 22 (Houston Press 1925; Houston-Post Dispatch 1925b; Galveston Daily News 1925) contain no mention of the Zavalas or of the planned ceremony. There is nothing in the minutes of the Texas Historical and Landmarks Association or the accounts of the next meeting of the Daughters of the Republic of Texas. Surprisingly, Miss Adina de Zavala's voluminous papers contain no hint about what transpired, and no mention is ever again made of the ceremony so long in the planning, and it would seem, so dear to her heart.

Not until an interview in 1968 with members of the family who were present at the 1925 ceremony, do we find any further information. Evidently funeral home employees removed what were believed to be the burials of Lorenzo de Zavala, his wife, and General Castrillon, loaded them into a wagon and transported them across to the battleground. The ceremony was under way when Victor de Zavala interrupted the proceedings demanding that the burials be replaced in the cemetery. He had apparently promised his father, Ricardo de Zavala, that his grandparent's graves would never be moved (Sentinel 1968; Baytown Sun 1968). One would expect that at this point the ceremony dissolved in confusion, and there is no reason to believe that the remains were not taken back and reburied in the Zavala cemetery, under Victor's personal supervision. However, no written record of this event has been found. The Settegast Funeral Home (now Settegast \& Kops) claims no records exist in their files, and no one has been found still surviving who was present at the ceremony.

Other than the installation of markers at the cemetery and home site in 1928 by the Texas Historical and Landmark Association (Houston Post-Dispatch 1928), and on the Lorenzo de Zavala and David Thomas grave sites by the State of Texas in 1931, no further action was taken toward recognizing the Zavala cemetery. The 43rd Legislature accepted title to the cemetery in 1933 (Texas House of Representatives 1933), and in 1934 Adina de Zavala and Lulu D. Hurst legally conveyed the cemetery to the state (Deed Records 1934 Vol. 949:423-424), its care then becoming the responsibility of the Board of Control. In 1936 the Texas Centennial Commission erected a marker to Peter Jefferson Duncan at the cemetery, and a commemorative marker at the home site. When the land surrounding the cemetery was purchased by the U. S. Government for an Ordnance Depot in 1939 , the cemetery was surrounded by a protective chainlink fence (Houston Chronicle 1941). Judging from newspaper photographs at that time, it was still intact and above water level. There then ensued a 25-year period of comparative peace and quiet in which the plot was bypassed and forgotten except by the family and older members of the community.

Interest in the cemetery was revived in 1964 by the sale of the Zavala portion of the government property to the Milray Corporation (Houston Post 1966). Considerable subsidence in the area had brought the water up to and over portions of the cemetery at high tide (ibid.). The Milray Corporation inquired into the possibility of having the cemetery designation removed so that they could purchase the one-acre plot from the State. Various legal opinions were advanced, the final conclusion being that this could only be 
accomplished by a legislative enactment (Texas Attorney General's Office 1964).

While this discussion was going on, the battleground and cemetery were transferred to the jurisdiction of the State Parks and Wildlife Department as part of a general reorganization. After a visit to the area in 1966, Attorney General Crawford Martin became concerned over the state of the cemetery. In 1967 he recommended that the Legislature take action to move it to a better location (Houston Post 1968). On July 2, 1968, the Texas House of Representatives (1968) adopted a resolution, H. S. R. 103, requesting the Parks and Wildlife Department to move the cemetery to the San Jacinto Battleground Park (Sentinel 1968). Local sentiment, as reflected in interviews published in the Channelview and Baytown newspapers, was not in favor of moving the graves. Family members recalled the 1925 incident (incorrectly reported as happening in 1928, by this time) and the fact that there were numerous unidentified burials there. Mrs. Eppie Higginbotham, granddaughter of Lorenzo de Zavala, is quoted as remarking, "They would never be sure they had the right bodies" (Sentinel 1968; Baytown Sun 1968).

In response to the Legislative directive, the Parks and Wildlife Department contacted a number of local funeral directors in an attempt to arrange for moving the burials. In each case, the professional opinion was expressed that there would be little use in going to the trouble and expense of attempting the transfer, since there would be nothing left in the graves to be moved, due to the saturated condition of the site (W.M. Gosdin, personal communication). The amount of family and community disapproval was also becoming evident. Permission was then obtained from the family descendants to move only the markers to the battleground park (Quick 1969; Gosdin 1980).

By this time, the cemetery was suffering from vandalism as well as flooding. The fence was disappearing beneath the water, and debris from the channel was scattered over the surface. On July 18,1968 , the Schlitzberger Memorials Company of Channelview moved all the markers and monuments (Table 4) to the San Jacinto Battleground Park (Muril Hart, personal communication). An area was set aside as the De Zavala Memorial Plaza, and the descendants of the family have been given the right to inter additional family members there (J. C. Martin, personal communication).
TABLE 4. MARKERS INSTALLED AT SAN JACINTO BATTLEGROUND

Emma S. de Zavala

Sidney de Zavala

David Thomas

1931 State Marker

Frederick Dulitz

Fred Nitsche

William Nitsche

Dr. Dunlap

Ricardo de Zavala

Lorenzo de Zavala

1931 State Marker

Jesse Higginbotham

Peter Jefferson Duncan 1936 State Marker

Charles Wilcox

Willa Folk (Mrs. L. T.)

Amy Inex Higginbotham

Louis Victor de Zavala 1975

Louis B. de Zavala 1980

\section{ADDITIONAL SITES}

Whitsell Cemetery. To the right of the road which traverses the property northwest to southeast, just beyond the houses at the gate, is a small area surrounded by a chainlink fence (Thompson 1981). This is apparently referred to as the Whitsell Cemetery (Sentinel 1968), the private cemetery of a family who once lived on the property. The fencing is the same as that which delimited the Zavala cemetery and was undoubtedly also installed by the U. S. Government when they owned the property.

Zavala Home Site. Registered at the Texas Archeological Research Laboratory in Austin as site 41 HR 32, this has been described as a clam shell beach. This badly eroded prehistoric midden site was once also the location of one or more 19th- to 20 th-centuries structures. Artifacts recently collected from the site by W. L. Fullen, date the historic occupation from the first half of the 19th century well into the 20 th century (author's personal observation). This general area has traditionally been considered to be the location of Lorenzo de Zavala's home, and historical markers have been erected on and near the site.

It seems to be undisputable fact that the original $\log$ house acquired by Lorenzo de Zavala (it was already standing when he bought the property) was 
located somewhere on the Point. Adina de Zavala wrote several descriptions of the house as she saw it when a child. She remembered it as a story-and-a-half house with a porch across the front. It sat on top of a rise, "commanding a fine view in every direction" (Zavala 1934). The old house burned sometime in the $1860-1870$ period, and Mrs. Zavala, who by this time was Mrs. Zavala Folk Hand, evidently built a new home somewhere nearby. Adina de Zavala remembered that many flowers in the garden at the second house were "brought down from the old one" (ibid.), implying that this house was located at a lower elevation from the original one. It is distinctly possible that the first house was located at the highest elevation of the Point, still well out of reach of the water. The site may have been removed or seriously impacted by later construction of buildings in that area which are shown on early maps. There seems to be considerable confusion about the actual location of the first house, and the later location of historical markers were more than likely inaccurate. An intensive historical records search and archaeological survey could probably clear up the confusion and determine which sites are still preserved and what finally became of the later house. Until this is done, the entire Point should be considered a sensitive area and left as much unaltered as possible. There are numerous remains of old house structures scattered over the area which have not been identified or examined.

Sites $41 \mathrm{HR} 40$ and $41 \mathrm{HR} 41$. These prehistoric shell midden sites at the very tip of the point, were first recorded by Worthington and Neyland in 1956-1957. By 1973, no trace was left above the water line (McGuff and Ford 1974:65).

Sites 41 HR 37, 41 HR 38, 41 HR 39, 41 HR 42. $41 \mathrm{HR} 43,41 \mathrm{HR} 44$. These six sites have not been examined or archaeologically assessed since 1956-1957. Fullen (personal communication) believes that several of these sites warrant testing to determine their potential for yielding important information on the prehistory of the Galveston Bay area.

\section{REFERENCES CITED}

\section{Atkinson, W. M.}

1925 Letter to Adina de Zavala, March 30. Barker Texas History Center, The University of Texas at Austin, Adina de Zavala Collection, File 2M149.
Baytown Sun

1968 De Zavala Cemetery Move Shocks CV, Baytown Residents. Muril Hart personal collection of photographs and clippings.

1969 Battleground Grave Markers Relocated. July 22. Muril Hart personal collection of photographs and clippings.

\section{Galveston Daily News}

1925 Article on San Jacinto Day celebration, April 22. Barker Texas History Center, The University of Texas at Austin, Map and Newspaper Collection.

Gosdin, W. M.

1980 Letter to Mr. John M. Flatten, Jr. September 22. Texas Parks and Wildlife Department files, Austin.

Harris County, Texas

Deed Records

Miss Adina de Zavala, et al to the State of Texas.

\section{Houston Chronicle}

1921 At Lynchburg There Lived a Noted Patriot, by Julia Beazley. January 23. Muril Hart personal collection of photographs and clippings.

1925 First Vice President of Texas and Wife to be Buried Tuesday on San Jacinto Battleground. April 19. Microfilm at Houston Chronicle office, Houston, Texas.

1941 Huge Ordnance Depot, to Cost $\$ 8,000,000$, is Going Up Now on Site of Old De Zavala Homestead On Ship Channel, by Charles Evans. September 7. Barker Texas History Center, The University of Texas at Austin, Lorenzo de Zavala clippings file.

\section{Houston Post}

1900 Lorenzo de Zavala's Grave. September 5. Barker Texas History Center, The University of Texas at Austin, Adina de Zavala Collection, file 2M149.

1966 Patriot's Cemetery Forgotten. De Zavala Grave Sliding into Ship Channel, by Harold Scarlett. April 17. Muril Hart personal collection of photographs and clippings. 
Houston Post (continued)

1968 New Burial Ground is Urged for Early-Day Texas Official, by William $\mathrm{H}$. Gardner. March 21. Muril Hart personal collection of photographs and clippings.

\section{Houston Post Dispatch}

1925a Article on San Jacinto Day celebration, April 19. Muril Hart personal collection of photographs and clippings.

1925b30,000 Texans Pay Tribute to Dead, April 22. Barker Texas History Center, The University of Texas at Austin, Map and Newspaper Collection.

1928 Scribe Scents Mystery and Fails to Find Where De Zavala Bronze Memorial Tablets Have Been Hid. Barker Texas History Center, The University of Texas at Austin, Biographical file for Lorenzo de Zavala.

Houston Press

192530,000 Go To Battleground. April 22. Barker Texas History Center, The University of Texas at Austin, Map and Newspaper Collection.

Kemp, L. W.

1944 Signers of the Texas Declaration of Independence. Anson Jones Press, Salado, Texas.

McGuff, P. R. and M. M. Ford

1974 Galveston Bay Area, Texas. A Study of Archeological and Historical Resources in Areas Under Investigation for Navigation Improvement. Texas Archeological Survey, The University of Texas at Austin, Research Report 36.

Quick, M.

1968 Letter to J. R. Singleton. March 11. File 68-481, State Attorney General's Office, Austin, Texas.

\section{Sentinel}

1968 De Zavala Remains Not to Succumb to Oily Depths of the Ship Channel. Vol. 3, No. 28, Channelview. Muril Hart personal collection of photographs and clippings.

Texas Attorney General's Office 1964 De Zavala Cemetery File. Austin, Texas.
Texas Historical and Landmarks Association

1925 Minutes of Regular Meeting. April 4. Barker Texas History Center, The University of Texas at Austin, Adina de Zavala Collection, File 2M149.

Texas House of Representatives

1933 Acts 43rd Legislature, H.C.R. No. 18. Filed May 13, 1933.

1968 Acts 60th Legislature, H.C.R. No. 103. Filed July 2, 1968.

Thompson, C. A., Company

1981 Survey Plat of 125.5828 Acre Tract of Land Located in Harris and Carpenter Survey A-28, Harris County, Texas. Drawing No. 1973-3. December 14.

Webb, W. P. (editor-in-chief)

1952 The Handbook of Texas. Vols. I and II. The Texas State Historical Association, Austin.

Wharton, C. R.

1925a Letter to Adina de Zavala, March 18. Barker Texas History Center, The University of Texas at Austin, Adina de Zavala Collection, File 2M149.

1925bLetter to Mrs. C. H. Milby, March 18. Barker Texas History Center, The University of Texas at Austin, Adina de Zavala Collection, File 2M149.

1925c Letter to Adina de Zavala, March 25. Barker Texas History Center, The University of Texas at Austin, Adina de Zavala Collection, File 2M149.

Zavala, Lorenzo de, Jr.

1838 Inventory of Lorenzo de Zavala Estate. Barker Texas History Center, The University of Texas at Austin, copy in Adina de Zavala Collection. 


\section{PEOPLE CONSULTED}

W. L. Fullen, Deer Park, amateur archaeologist Muril Hart, Channelview, newspaper woman

W. M. Gosdin, Texas Parks and Wildlife Department, Austin

Orion Knox, Texas Parks and Wildlife Department, Austin

Sue Moss, Texas Parks and Wildlife Department, Austin

Bert Rader, Corps of Engineers, Galveston

LaVerne Herrington, Texas Historical Commission, Austin

Patricia Patterson, Texas Historical Commission, Austin

Henry Guerra, Angelus Funeral Home, San Antonio

Porter Loring, Jr., Porter Loring, San Antonio

Settegast \& Kops, Houston

Catholic Chancery Office, San Antonio

J. C. Martin, San Jacinto Monument

Ernest Connally, National Park Service, Washington D. C.

\section{COLLECTIONS EXAMINED}

University of Texas Archives, Austin (Adina de Zavala, Louis Kemp, C. R. Wharton collections)

University of Texas Map and Newspaper Collections, Austin

John Peace Library, The University of Texas at San Antonio

Daughters of the Republic of Texas Research Library, San Antonio 

